\title{
Health collapse in Manaus: the burden of not adhering to non-pharmacological measures to reduce the transmission of Covid-19
}

\author{
Colapso na saúde em Manaus: o fardo de não aderir às medidas não \\ farmacológicas de redução da transmissão da Covid-19
}

\author{
Ivana Cristina de Holanda Cunha Barreto', Raimundo Valter Costa Filho², Ronaldo Fernandes \\ Ramos² $^{2}$ Luciana Gonzaga de Oliveira ${ }^{3}$, Natália Regina Alves Vaz Martins³, Fabrício Vieira \\ Cavalcante ${ }^{\mathbf{3}}$, Luiz Odorico Monteiro de Andrade', Leonor Maria Pacheco Santos ${ }^{\mathbf{3}}$
}

DOI: $10.1590 / 0103-11042021131141$

\begin{abstract}
This article aims to compare the evolution of Covid-19 in Manaus and Fortaleza, two epicenters of the pandemic in 2020, analyzing legal measures by local governments and levels of social isolation. An algorithm was defined to calculate the Homestay Index (HSI), using data from the Google Mobility Report. We analyzed the decree's timeline, the HSI evolution, the Covid-19 incidence and the number of deaths from March/2020 to January/2021. The population of Fortaleza was exposed to more consistent measures of social distancing than that of Manaus. Longer homestay was observed from March to May 2020 and Fortaleza achieved higher and more lasting levels. As of June 2020, the HSI fell, notably in Manaus, reaching levels below zero in late December. As an aggravating factor, the government decreed broad isolation in Manaus on December 23, 2020, but after protests it was repealed on December 26, 2020. A judicial decision determined the complete closure in Manaus on January 2nd 2021, but it was too late: the SUS collapsed with an exponential increase in deaths. In Fortaleza, the demand for health services was high, but under control. We consider that only the strict application of non-pharmacological measures and mass immunization can prevent further deaths.
\end{abstract}

KEYWORDS Covid-19. Pandemics. Decrees. Social isolation. Unified Health System.

1 Fundação Oswaldo Cruz (Fiocruz) - Eusébio (CE), Brasil.

ivana.barreto@fiocruz.br

2 Instituto Federal de Educação, Ciência e Tecnologia do Ceará (IFC)

- Fortaleza (CE), Brasil.

3 Universidade de Brasília (UnB) - Brasília (DF), Brasil.
RESUMO Objetivou-se comparar o comportamento da Covid-19 em Manaus e Fortaleza, dois epicentros da pandemia em 2020, analisando medidas legais dos governos locais e níveis de isolamento social. Definiu-se um algoritmo para calcular o Índice de Permanência Domiciliar (IPD), com dados do Google Mobility Report. Analisaram-se a linha do tempo dos decretos, a evolução do IPD, da incidência de Covid-19 e do número de óbitos de março/2020 a janeiro/2021. A população de Fortaleza esteve exposta a medidas de distanciamento social mais consistentes que as de Manaus. Foi observado, de março a maio de 2020, uma maior permanência domiciliar, e Fortaleza atingiu níveis mais elevados e duradouros. A partir de junho, o IPD caiu, sobretudo em Manaus, atingindo níveis abaixo de zero no final de dezembro. Devido a isso, o governo decretou amplo isolamento em Manaus em 23/12/2020, mas após protestos, revogou-o em 26/12/2020. Uma decisão judicial determinava o fechamento completo em Manaus em 02/01/2021, mas foi tarde demais: o SUS entrou em colapso com aumento exponencial dos óbitos. Em Fortaleza, a demanda aos serviços de saúde estava elevada, mas sob controle. Considerou-se que somente a aplicação rigorosa de medidas não farmacológicas e imunização em massa poderiam evitar mais mortes.

PALAVRAS-CHAVE Covid-19. Pandemias. Decretos. Isolamento social. Sistema Único de Saúde. 


\section{Introduction}

The first case of Covid-19 in Brazil was registered on February 26, 2020, and community transmission was recognized throughout the territory on March 20 of that same year' ${ }^{1}$. Due to the lack of a vaccine and specific and effective drug treatments, the World Health Organization (WHO), based on the experience of controlling viral neo-epidemics, such as the Middle East Respiratory Syndrome (Mers), recommended non-pharmacological measures to the control of the Covid-192 pandemic. Among the nonpharmacological measures was social distancing, triggered by the suspension or reduction of non-essential activities in the public and private sectors, such as public administration activities; school, commercial, industrial, tourism activities; events in general; among others.

The WHO recommended: the association of social distancing measures with health control measures, such as the investigation of suspected cases of Covid-19 and its contacts; the imposition of quarantine on suspected and confirmed cases of Covid-19; the testing of all suspected cases and the most exposed or vulnerable groups; and, furthermore, the recommendation to use masks, alcohol gel and soap for hand hygiene. Social measures - such as the guarantee of a minimum income and food for vulnerable and jobless populations - are also fundamental for the fulfillment of social distance. The implementation of these measures requires national inter-institutional and inter-sectoral coordination, with a clear political centrality aimed at controlling the pandemic, based on scientific evidence and aligned with the $\mathrm{WHO}^{\mathbf{3 , 4}}$.

According to data from the Ministry of Health (MS), from February 2020 to January 31,2021 , in the country, there were $9,202,791$ confirmed cases of Covid-19 and 224,534 deaths from the disease, with a mortality rate of $2.5 \%$. In addition to being continental, Brazil is a federative country with three spheres of government, being the only one in the world with more than 100 million inhabitants and a public health system, constitutionally universal and decentralized at the municipalities level ${ }^{6}$. However, the entire power of the Unified Health System (SUS) has been undermined by economic measures of fiscal austerity, such as Constitutional Amendment No. 95. In addition, there has been a weakening of its inter-federative bodies of consensual management of the SUS, in particular, the Tripartite Inter-manager Commission, composed of representations of federal, state and municipal administrations. The breach of consensual decisions among managers was made clear by the recent manifestation of the National Council of Health Secretaries (Conass), declaring itself against the permission given by the federal government for the purchase of 33 million doses of vaccines by private companies, once that this purchase could weaken the National Immunization Program and, consequently, undermine the control of the Covid-19 pandemic ${ }^{7}$.

Manaus, capital of Amazonas, had already been the scene of high incidence and mortality rates by Covid-19 in May 2020, which even caused a collapse of the funeral system during the first wave of the pandemic, bringing suffering to its population. In the last weeks of December 2020 and the first weeks of January 2021, a new wave of cases left the city in shock, bringing the collapse of the municipal health system due to the lack of infirmary beds, Intensive Care Unit (ICU) beds and oxygen. Meanwhile, other capitals in the country managed to maintain control, at least until early 2021, of the demand for health services. This is the case of Fortaleza, which had a sharp spike in Covid-19 deaths shortly after Manaus, in June 2020, but did not collapse in January 2021.

In this article, the authors intend to analyze whether the legal measures of local governments and the levels of social isolation may have contributed to the collapse of the SUS in the city of Manaus, comparing with the behavior of the Covid-19 pandemic in Fortaleza, two municipalities that, in mid-2020, were considered the epicenters of the first wave of the pandemic. 


\section{Methodology}

The capitals under study were compared in terms of some sociodemographic and health indicators, such as the Municipal Human Development Index (MHDI) and the Gross Domestic Product (GDP) per capita ${ }^{\mathbf{8}, \mathbf{9}}$, estimated population ${ }^{10}$, urban demographic density ${ }^{9}$ and schooling rate from 6 to 14 years 9 . The evolution, between March and June 2020, of the rate of physicians was obtained by the ratio between the number of available physicians ${ }^{11}$ and the estimated population for $2020^{10}$, multiplied by one thousand inhabitants. Similarly, ICU bed rates were calculated as the ratio between the number of adult ICU beds available in the National Register of Health Establishments (CNES) in the observed period $^{11}$ and the estimated adult population in each capital based on the 2010 census $^{\mathbf{1 2}}$, multiplied by a thousand adults.

To infer the reduction in the circulation of people and, therefore, reduction in the probability of virus transmission, the Homestay Index (HSI) was defined, calculated based on data published in the Google Mobility Report $(\mathrm{GMR})^{\mathbf{1 3}}$. It is a score containing the percentage change in the average length of stay of individuals in places such Residential, Work, Market \& Pharmacy, Parks, Traffic \& Stations compared to the average length of stay for each day of the week in the pre-pandemic period (January 3rd 2020 to February 2nd 2020). GMR measurements are based on the use of smartphones with the Android operating system. According to Statcount ${ }^{14}$, a website specializing in computer network traffic analysis, the Android system, maintained by Google, is present in around $85 \%$ of smartphones that access the internet in Brazil since the beginning of the pandemic. The report from the Newzoo Consultancy ${ }^{15}$ points out that $45.6 \%$ of the Brazilian population is an active user of these devices, which places Brazil in fourth place in the world ranking, losing only to China, India and the United States. Thus, this study assumes that

the GMR can be considered a good proxy for population mobility in the cities surveyed.

The HSI is a relative index, which aims to compare the effectiveness of measures of social distancing coordinated by the government between locations. The higher the index, the longer the residential stay, and the lower the circulation of people in public areas, suggesting a decrease in the probability of exposure of people susceptible to the new coronavirus.

To build the algorithm and calculate the HSI from the GMR data, take:

$\mathrm{X} 1$ : Percentage variation in home permanence;

X2: Percentage change in Markets \& Pharmacies permanence;

X3: Percentage change in work permanence;

X4: Percentage change in Traffic \& Stations permanence;

X5: Percentage change in Retail \& Leisure permanence;

X6: Percentage change in Parks permanence;

The sum of the differences related to home stay (DD) is then:

$D_{\mathrm{D}}=\left(X_{1}-X_{2}\right)+\left(X_{1}-X_{3}\right)+\left(X_{1}-X_{4}\right)+\left(X_{1}-X_{5}\right)+\left(X_{1}-X_{6}\right)$

The average variation of the difference between the household rate and the others results in the HSI:

$$
\begin{aligned}
& H S I= \\
& \frac{D_{\mathrm{D}}=}{5}=\frac{\left(\left(X_{1}-X_{2}\right)+\left(X_{1}-X_{3}\right)+\left(X_{1}-X_{4}\right)+\left(X_{1}-X_{5}\right)+\left(X_{1}-X_{6}\right)\right)}{5} \\
& H S I=\frac{\left(5 X_{1}-\left(X_{2}+X_{3}+X_{4}+X_{5}+X_{6}\right)\right)}{5} \\
& H S I=\frac{X_{1}-\left(\left(X_{2}+X_{3}+X_{4}+X_{5}+X_{6}\right)\right)}{5}
\end{aligned}
$$

Or: 
$H S I=$ Home $-(($ Markets \& Pharmacies + Work + Traffic $\&$ Stations + Retail $\&$ Leisure + Parks))

5

The HSI is, then, the result of the difference between the residential stay and the average of the stays measured for the other locations. It is noteworthy that, despite being an average between percentages, it does not represent the percentage of home stay, but an index in which a positive score means less movement of people compared to the pre-pandemic period (January 3rd 2020 to February 2nd 2020).

Data on the number of notified cases and deaths were collected from the portal Coronavirus Brasil5. The incidence rate was calculated considering the estimated population available in the IBGE - Brazilian Institute of Geography and Statistics - Automatic Recovery System (Sidra) ${ }^{16}$.

The recovery and extraction of data on decrees and laws that instituted non-pharmacological measures to contain the epidemic by state governments, dates of adoption of social isolation and relaxation applied to the states of Amazonas and Ceará in the period from February 2020 to 31 from January 2021 were extracted on the website17.

\section{Results}

\section{Comparison of selected indicators for Fortaleza and Manaus}

The comparison of selected sociodemographic and health indicators for the two capitals studied is shown in table 1. As for the Municipal HDI indicators, estimated population and schooling rate, there are no major disparities. The urban demographic density in Fortaleza is twice that observed in Manaus, a difference that could have important effects on the transmission rate of Covid-19, notably providing an increase in this rate in Fortaleza compared to Manaus. Furthermore, Manaus also compares positively in relation to GDP per capita, which is $43 \%$ higher than Fortaleza. On the other hand, all health care indicators in Fortaleza are more favorable, with greater availability of infirmary and ICU beds, as well as a higher ratio of doctors per inhabitant.

Table 1. Selected sociodemographic and health indicators. Fortaleza and Manaus, 2010 and 2020

\begin{tabular}{|c|c|c|c|}
\hline Indicator & Base date & Manaus & Fortaleza \\
\hline$\left.M H D\right|^{8}$ & 2010 & 0.737 & 0.754 \\
\hline Estimated population $\mathbf{1 0}$ & 2020 & $2,219,580$ & $2,686,612$ \\
\hline 2010 population (Census) $\mathbf{1 2}$ & 2010 & $1,802,014$ & $2,452,185$ \\
\hline Total area $\mathbf{9}$ & 2010 & $11,491.09$ km² & $314.93 \mathrm{~km}^{2}$ \\
\hline Urban area12 & 2010 & $859.86 \mathrm{~km}^{2}$ & $314.93 \mathrm{~km}^{2}$ \\
\hline Urban demographic density $\mathbf{1 2}$ & 2010 & 2,095 inhab/km² & 7,786 inhab $/ \mathrm{km}^{2}$ \\
\hline GDP per capita 9 & 2018 & $R \$ 36,445.75$ & $R \$ 25,356.73$ \\
\hline Schooling rate from 6 a 14 anos $^{9}$ & 2010 & $94.2 \%$ & $96.1 \%$ \\
\hline \multirow[t]{2}{*}{ Ratio of physicians per 1,000 population"1 } & Mar 2020 & 1.66 & 2.55 \\
\hline & Jun 2020 & 1.68 & 2.63 \\
\hline \multirow[t]{2}{*}{ ICU bed rate per adult' } & Mar 2020 & 0.22 & 0.53 \\
\hline & & 0.38 & 0.55 \\
\hline
\end{tabular}

Source: Brazil|8; IBGE9-10; Brazi|11; IBGE12. 


\section{Period from March to November 2020: the first wave of the pandemic}

The first non-pharmacological contingency measures, such as the use of masks, social isolation and restrictions on the functioning of establishments, were issued on the same day in the two analyzed Covid-19 epicenters. Graph 1 shows the timeline of isolation and relaxation measures in Fortaleza and Manaus, determined by state decrees, laws and court decision, published from March 16 to January 31, 2021, compared to the HSI, confronted with the epidemiological data on incidence rates and moving average of the number of deaths registered in the period.

The state of Ceará published a total of nine decrees (six until November 30th 2020 and three between December 1st 2020 and January 31st 2021). There were four legal isolation measures published between March 16 and 23, which were extended every 15 days, until July 11, when there was a reopening schedule for each type of establishment, provided that it respected the number of people in relation to: location capacity, hygiene conditions, distances between people and waiting time.

The state of Amazonas issued a total of 14 decrees (eight until November 30th 2020 and six between January 12th 2020 and January 31st 2021). The five isolation decrees published early on, between March 16 and March 31, were extended over the months, every 15 days, until June 1st. The first relaxation decree reopened malls; next, bars, restaurants, face-to-face meetings, and then toy stores, stationery and offices. However, the opening decrees imposed conditions for each establishment, such as hygiene measures, fewer people in relation to the capacity of the place, distances between people and waiting time for service. 
Graph 1. Moving averages for the last 7 days of the incidence rate of Covid-19 per 100 thousand inhabitants, absolute number of deaths, Home Stay Index and timeline of legal measures of social isolation and relaxation. Fortaleza and Manaus 2020-2021
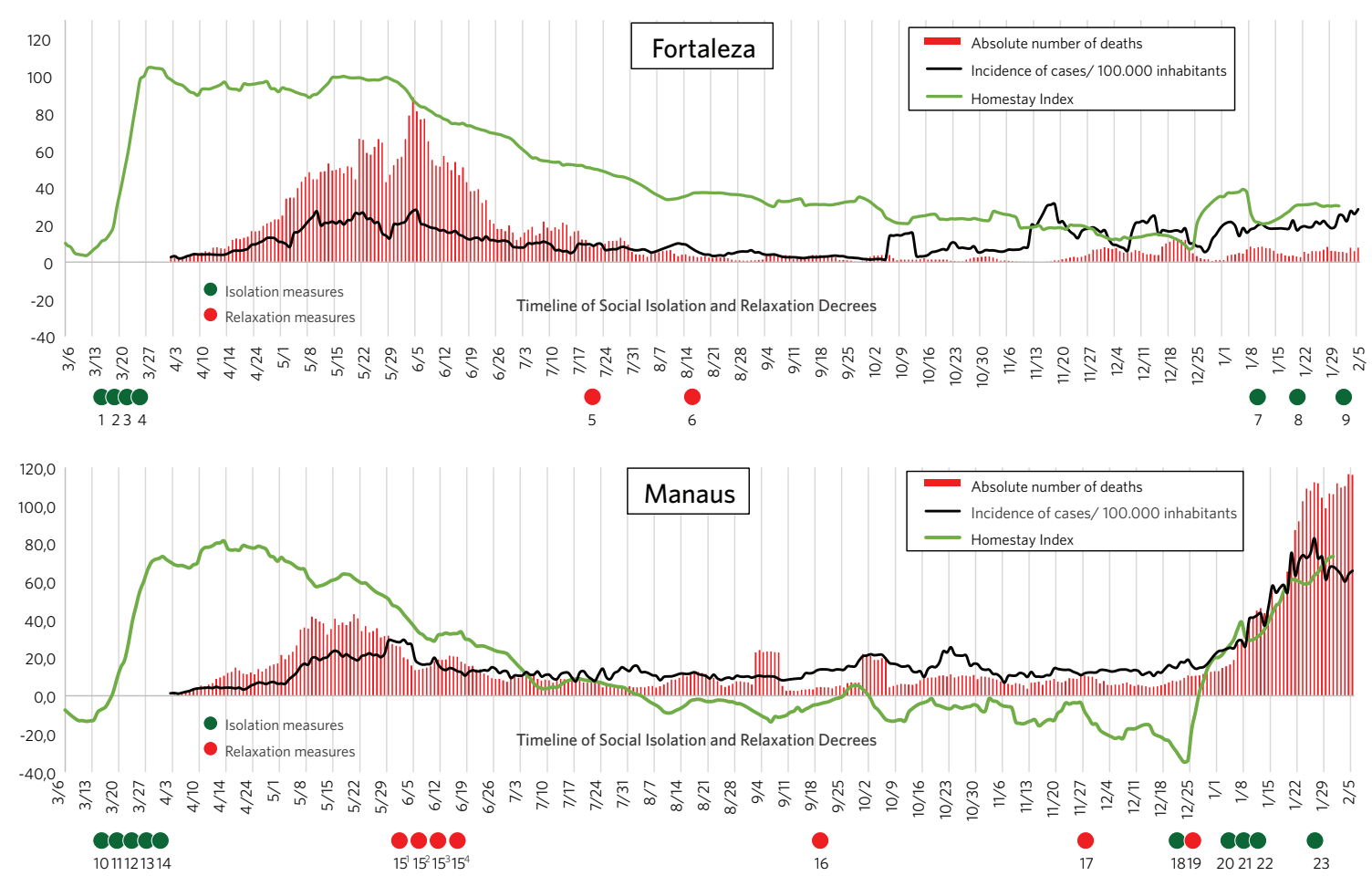

FORTALEZA - State decrees for social containment and relaxation

1. Decree No. 33510 of March 16, 2020: suspends municipal meetings and events, official trips and isolates people diagnosed with Covid-19.

2. Decree No. 33519 of March 19, 2020: suspends classes (public/private), nonessential commercial establishment, events with more than 100 people and services to users in public institutions.

3. Decree No. 33521 of March 21, 2020: recommends that services must be by take away, drive-thru or delivery.

4. Decree No. 33523 of March 23, 2020: establishes essential places such as bakeries, supermarkets, car repair shops. (Deadlines for isolation decrees extended, every 15 days until 11 July).

5. Decree No. 33671 of July 11, 2020: regionalization of isolation and reopening schedules for each type of establishment.

6. Decree No. 33704 of August 5, 2020: imposes conditions for each establishment (number of people and distance in relation to venue capacity, hygiene conditions and waiting time)

7. Decree No. 33899, of January 9, 2021: social isolation measures are extended until January 31, 2021 in the State of Ceará.

8. Decree No. 33904, of January 21, 2021: until January 31, 2021, the social isolation measures provided for in Decree No. 33519 of March 19, 2020 remain in force in the State of Ceará.

9. Decree No. 33913, of January 30, 2021: until February 07, 2021, the social isolation measures provided for in Decree No. 33519, of March 19, 2020 remain in force in the State of Ceará.

MANAUS - State decrees for social containment and relaxation

10. Decree No. 42061 of March 16, 2020: suspends public and private classes, municipal meetings and events, official trips and isolates people diagnosed with Covid-19.

11. Decree No. 42063 of March 17, 2020: suspends non-essential commercial establishments, events with more than 100 people (like shows).

12. Decree No. 42085 of March 18, 2020: suspends face-to-face service to users in public institutions.

13. Decree No. 42087 of March 19, 2020: suspends intercity road transport 14. Decree No. 42145 of March 31, 2020: closure of visits to prisons (Deadlines for isolation decrees have been extended, every 15 days, until May 28.)

15. Decree No. 42330 of May 28, 2020: opening: on June 01 shopping malls, public institutions, religious temples; June 06 bars and restaurants; June 7 face-to-face meetings; June 15 toy stores, stationery and offices.

But it imposes conditions for each establishment: number of people relative to local capacity, hygiene conditions, distances between people and waiting time.

16. Decree No. 4906, of September 18, 2020: suspends for 60 (sixty) days, the Ponta Negra Tourist Complex beach.

17. Law No. 2,709, of November 27, 2020: reopening of restaurants, bakeries, supermarkets and establishments that provide meals in the municipality of Manaus, with restrictive measures.

18. Decree No. 43234, of December 23, 2020: prohibits, in the period from December 28, 2020 to January 11, 2021, the opening of non-essential commerce and the holding of commemorative meetings, including New Year's.

19. Decree No. 43236, of December 28, 2020: revokes the closing of non-essential trade previously determined by Decree No. 43434.

20. Court decision of January 2,2021, at the request of the Public Defender of Amazonas, maintains the validity of Decree No. 43234, prohibiting the opening of nonessential trade.

21. Decree No. 5001, of January 4, 2021: declares an emergency situation in the Municipality of Manaus, for a period of one hundred and eighty days, due to the pandemic caused by the new Coronavirus.

22. Decree No. 4999, of January 4, 2021: suspended, until March 31, 2021, any and all attendance to the public, face to face, by the Municipal Public Administration.

23. Decree No. 43303, of January 23, 2021: extends the temporary restriction on the movement of people on public roads, in all municipalities of Amazonas, 24 hours a day (LOCKDOWN).

Source: Self elaborated - Homestay Index (HSI) based on Google Mobility Report (GMR) ${ }^{\mathbf{1 3}}$, Number of cases and deaths based on the Coronavirus Brasil dashboard5, Incidence rate calculated based on the estimated population available in the IBGE (Sidra) ${ }^{\mathbf{1 6}}$. 
It should be noted that, in March, right after the publication of the first containment measures, the HSI showed expressive growth in both capitals. However, in Manaus, the index was much lower and remained for a shorter period, starting to show negative values as of August, indicating that the population spent more time on the street than at home. In the state of Amazonas, the openings were authorized between 1st and 15th of June, still in the middle of an epidemic in Manaus, both from the point of view of incidence and deaths due Covid-19. The first opening decree, dated June 1, 2020, prioritized the operation of shopping malls, public agencies and religious temples. In Fortaleza, home stay was much longer and slowly declined, even after the opening decrees in July and August, remaining at lower values, but still positive, until the end of November 2020. In Fortaleza, openings were authorized as of July 11, when there was already a downward trend in both the incidence of cases and deaths due to Covid-19 (graph 1).

During this first period of study, the more detailed analysis by place of permanence in the HSI shows negative values in Manaus from August onwards, as a result of a longer permanence in Traffic \& Stations and Work, especially between October and November. On the other hand, in Fortaleza, the population's permanence pattern is distinct, with a predominance of Market \& Pharmacy, followed by Traffic \& Stations (graph 2).

Graph 2. Evolution of the Homestay Index compared to other places of permanence of the population. Fortaleza and Manaus 2020-2021
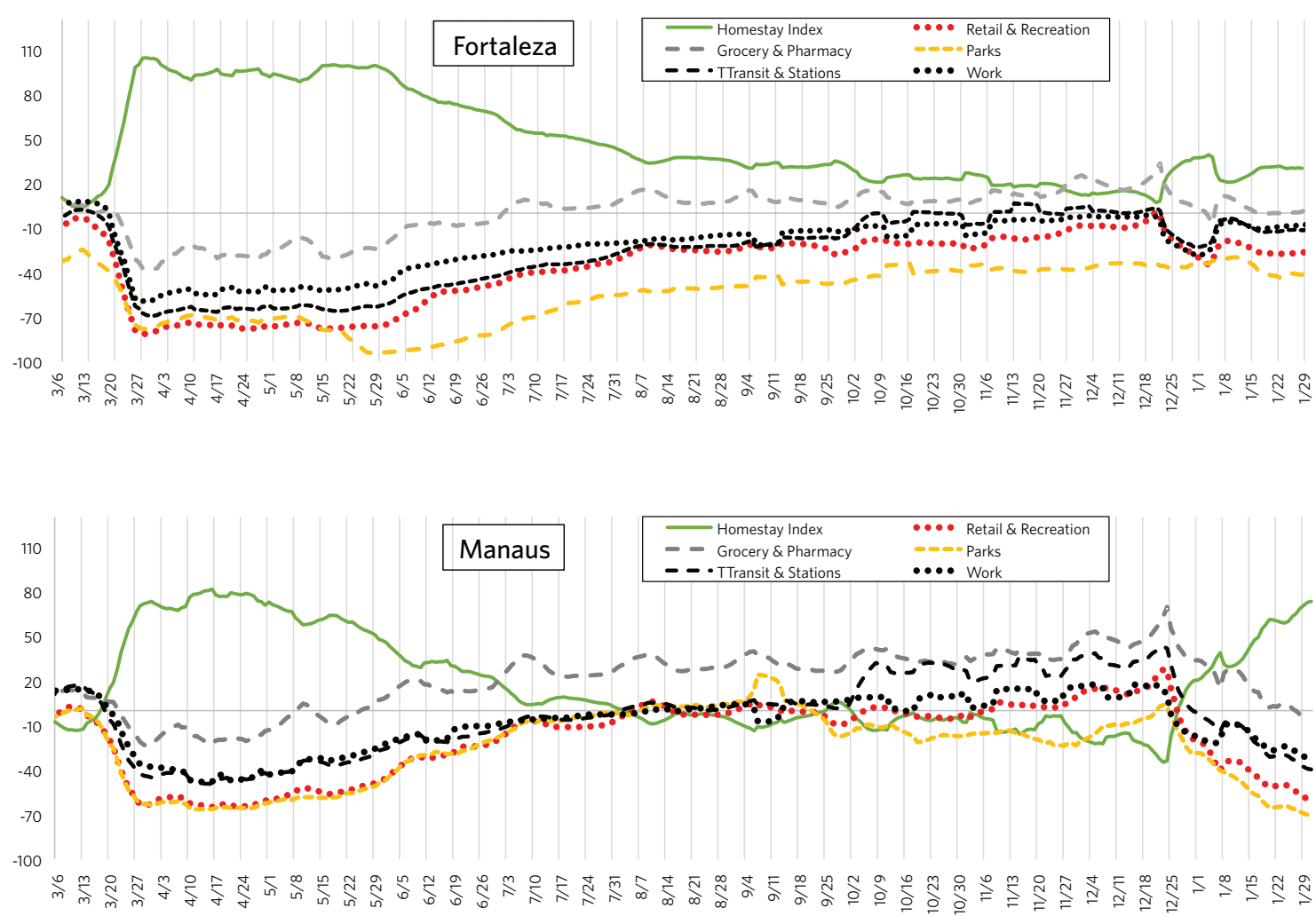


\section{Period from December 2020 to January 2021: the collapse in Manaus}

On December 23, the governor of Amazonas published Decree No. 43,234, determining that shopping malls, floating ships, bars and non-essential commercial establishments could not operate for a period of 15 days. It also prohibited commemorative meetings in public spaces, clubs and condominiums, including on New Year's Eve. Gyms, markets, fairs, notary offices and mechanical workshops, on the other hand, would be allowed to function (graph 1).

The population, businessmen, store employees and street vendors protested emphatically against the restrictive measures that determined the closure of trade. In response to popular pressure, the governor withdrew through Decree No. 43,236 and released the operation of general commerce, with only a few time restrictions (graph 1 ).

In this period, the HSI shows negative values in Manaus, as a result of longer stay in Retail \& Leisure, Traffic \& Stations, Markets \& Pharmacies (graph 2), indicating typical end-of-year movement from the beginning of October, increasing until the end of December.

On January 2, the Amazonas Court accepted the request of the Public Defender's Office and ordered the total suspension of activities considered non-essential for a period of 15 days. The judge even predicted the use of police force to 'preserve public order'. On January 14, the governor announced Decree No. 23,282, which prohibited the movement of people in Manaus between 7:00 pm and 6:00 am. The measure took effect on January 15 and had a period of 10 days. On January 27, the Mayor and Health Secretary of Manaus were arrested, based on inadequate management of Covid19 and vaccination.

The sequence of facts described above indicates an administrative disobedience of such an order that the intervention of the Public
Defender and the Judiciary was necessary to re-establish social isolation on January 2, 2021, already under the chaos and collapse of the SUS in the municipality. As for the permanence in homes, the HSI, which had negative values, evolved sharply in just a few weeks (graph 1).

However, it was too late: in December 2020 and January 2021, Manaus' public (SUS) and private health systems collapsed. While, in the period from April to December 2020 (270 days), 3,380 deaths from Covid19 were reported in Manaus residents, in January 2021 (31 days), 2,195 deaths were reported, showing a new and avoidable sharp peak of mortality by Covid-19 (graph 3). On January 14, dozens of patients died of asphyxia due to the lack of oxygen in the public hospital network in Manaus, an event that shocked the Brazilian population and all of humanity. The Ministry of Health and the government of the State of Amazonas followed the acceleration of cases, but did not take effective measures in time. Days later, this tragedy was repeated in other cities in the Amazonas' countryside.

In Fortaleza, legal measures of social isolation have been extended by state decrees since August 2020. The HSI was always higher than that registered in Manaus, but it declined throughout December, reaching very low values, reflecting an increase in permanence both in Parks and in Retail \& Leisure during the end-of-year festivities (graph 2). By the decree of January 9, 2021, the social isolation measures were extended in the state of Ceará until January 31, 2021. Soon after this decree, there was also a corresponding increase in the HSI, which rose consistently.

Comparatively, in January, there were 181 deaths in Fortaleza. The incidence rate of cases, which had been increasing from December 25 th, reached 25 per 100,000 inhabitants on January 15th, the same level reached in May 2020, just before the high incidence peaks, and, above all, of mortality, which occurred in the city in June 2020 (graph 
1). In Fortaleza, home stay was consistently higher during the study period; it went down a lot during the end-of-the-year festivities, as a result of more permanence in Markets \& Pharmacies, but it never reached values below zero. Soon after the government decree of January 8, 2021, extending the isolation until January 31 , there is an increase in the HSI in Fortaleza. For reasons that could not be investigated in the present study, the population of
Fortaleza seems to have been convinced of the importance of isolation measures and adhered to them consistently.

It is important to highlight that, even with the highest HSI, Fortaleza presented incidence rates of around 25 cases per 100,000 inhabitants in May 2020, and a mortality rate of 3.5 per 100,000 inhabitants, levels considered high (graph 3).

Graph 3. Moving averages for the last 7 days of the mortality rate for Covid-19 per 100,000 inhabitants. Fortaleza and Manaus $2020-2021$

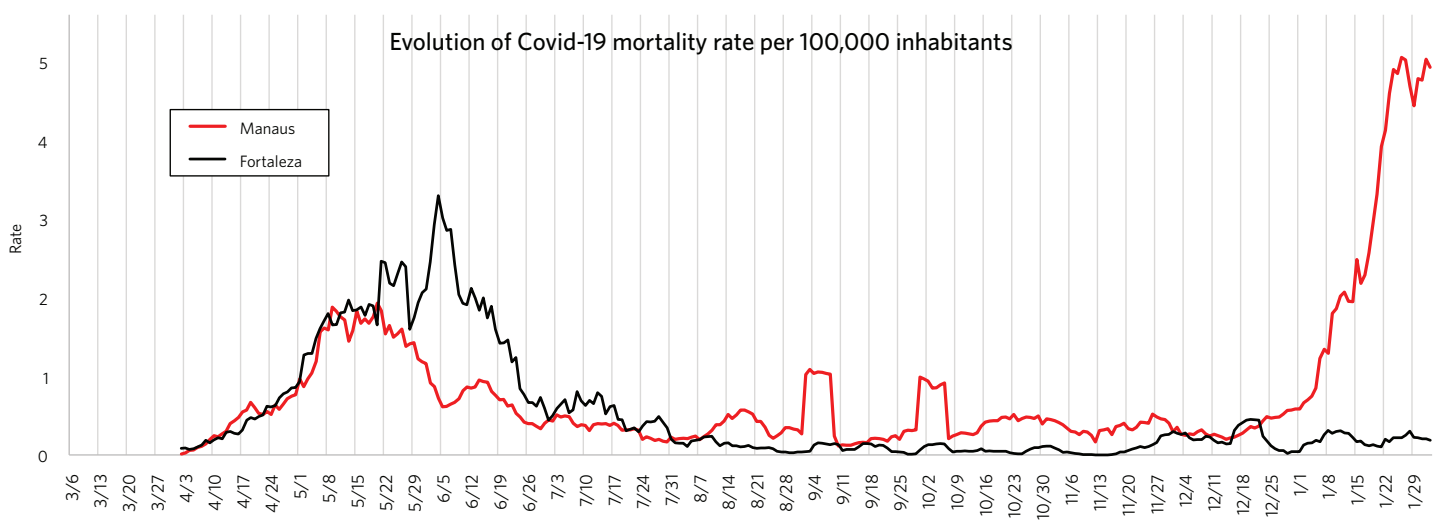

Source: Self elaborated - Number of deaths based on Coronavírus Brasil dashboard5, Mortality rate calculated based on estimated population available in the IBGE (Sidra) ${ }^{\mathbf{1 6}}$.

\section{Discussion}

The present work analyzed whether the legal measures of social isolation of local governments and the levels of social isolation may have contributed to the collapse of the SUS in the city of Manaus, compared to the behavior of the Covid-19 pandemic in Fortaleza.

The Health Law Research and Studies Center (Cepedisa) of the Faculty of Public Health of the University of São Paulo published the 'Rights in the pandemic bulletin: mapping and analysis of legal norms in response to Covid-19 in Brazil', in which it analyzed the 3,049 standards published within the Union in $2020^{18}$. It can be seen that, in most of these measures, there was an emphasis on economic actions taken by the federal government from January to June 2020 to confront Covid-19. In that period, there were 317 productions of standards by the Ministry of Economy, followed by professional councils, with 308 publications ${ }^{19}$. Few federal standards have been published in the health area according to Cepedisa.

It is noted that the municipality of Manaus did not achieve great adherence to social isolation. On the other hand, the state of Ceará, in the months of March to May 2020, determined incisive measures, such as a daily fine for nonessential establishments that opened, and the prohibition of the movement of people through the city, in order to reduce the incidence of the disease. During this same period, the 5th 
Public Finance Court determined the operation of beauty salons in the city of Manaus, considering them as an essential service ${ }^{\mathbf{1 8}}$.

A mathematical modeling study carried out by Li et al. ${ }^{20}$, which aimed to understand the association of the introduction and intensification of non-pharmacological measures with the level of transmission of Sars-CoV-2 in 131 countries, measured by the time-varying reproduction number (R), evidenced that isolated non-pharmacological measures, including school closing, workplace closure, prohibition of public events, prohibition of meetings of more than ten people, specific conditions for leaving the house and internal movement limits, are associated with reduced transmission of Sars-CoV-2. However, the effects of the introduction and intensification of these non-pharmacological measures do not manifest until 1-3 weeks after their implementation. Likewise, the increase in the virus transmission rate was also delayed when non-pharmacological measures were suspended, with this effect taking even longer. In the present study, it was observed that the sharp fall in HSI from June 2020 in Fortaleza and Manaus, which was particularly pronounced in the second municipality, coincided with an increase in the incidence rate and absolute number of deaths in the two municipalities from November and December of the same year. It must be emphasized that at no time was there any interruption in community transmission of Covid-19. In January 2021, the incidence rate continued to rise sharply, and mortality assumed catastrophic dimensions in Manaus.

Also, political consequences and low adherence to non-pharmacological measures to control Covid-19 in the state of Amazonas triggered a crisis in health systems ${ }^{23}$, which were already fragile, as in the city of Manaus ${ }^{24}$. In addition, the relaxation of containment measures during the course of the Covid-19 epidemic, both in Manaus and in Fortaleza, may have been one of the factors for the increase in epidemic levels in these locations ${ }^{23}$. This fact may have contributed to the emergence of new variants of Sars-CoV-2 in the state of Amazonas, with mutations in the Spike protein common to strains B.1.1.7 and B.1.351, a fact that has raised concerns around the world due to to a greater probability of transmissibility of these new strains ${ }^{\mathbf{2 5 , 2 6}}$.

This study, in an unprecedented way, brought as a contribution the creation and analysis of the HSI from open access data. The relevance of the HSI in the interpretation of population mobility in two large urban centers (pandemic epicenters) was demonstrated in this research. The validity and sensitivity of this new indicator were evident, as it responds quickly to variations in home stay resulting from legal requirements for isolation and relaxation. However, it was not within the scope of the study to analyze the relationship of HSI with population adherence, nor to deepen the analysis of its relationship with the incidence and/or number of deaths, which depend on several other factors related to the media (and Fake News) and the organization of health and epidemiological surveillance systems ${ }^{20}$.

Another important consequence of the pandemic is the impoverishment of the population. People from lower economic classes, who were already living with meager wages, during the pandemic, were cut off from their jobs or had their wages reduced. State and municipal governments, in an attempt to overcome this situation, exempted the population from water and electricity bills, distributed basic food baskets; and the federal government, at the initiative of the National Congress, created the Emergency Aid, but housing conditions and lack of sanitation were not topics for discussion or actions during this period ${ }^{\mathbf{2 1}}$.

Among the limiting factors of this study, there is the fact that a qualitative data collection was not carried out with the population to investigate possible reasons for adherence to isolation measures in the municipalities included in the research, as well as the nonperformance of the control of the confounding variables. Plausible hypotheses that could not 
be investigated are, on one hand, motivational aspects and, and on the other, even denial attitudes towards the pandemic. Another limitation refers to the challenge of implementing measures of social distancing, sanitary control (alcohol in gel, soap for hand hygiene) and the imposition of quarantine on suspected and confirmed cases of Covid-19 in very lowincome populations that live in subnormal agglomerations (favelas). These measures assume that the place of residence is large, ventilated, has treated water and cleaning material available, which, in most cases, is a fallacy for the lower-income population ${ }^{21,22}$.

Although the data show a higher percentage of adherence to non-pharmacological measures in Fortaleza, when compared to the city of Manaus, a study carried out in the northeast region of Brazil reported that, in epidemiological week 24, 2020 (June 7 to 13), the occupation of ICU beds in the state of Ceará already reached $90 \%{ }^{27}$. As of January 2021, there was a linear increase in the incidence of Covid-19 in Fortaleza ${ }^{\mathbf{2 8}}$, and on February 9, 2021, according to data from IntegraSUS Ceará, $91.8 \%$ of the ICU beds in the capital were occupied ${ }^{29}$.

\section{Final considerations}

The HSI proved to be a useful index to monitor the levels of social isolation and its behavior when adopting legal measures to intensify or relax it, and can be a reference for decisionmaking by managers. The analysis of data on the incidence of cases and deaths from 2020 to February 2021 in the two capitals made it clear that, at no time, the pandemic was controlled, and community transmission continued to occur. In conclusion, it is imperative to strictly apply non-pharmacological measures, carry out more tests per population, carry out testing in suspected cases of Covid-19, trace contacts of confirmed Covid-19 cases, perform quarantine by people confirmed or under suspicion of Covid-19, the increase in genomic surveillance of the virus in Brazil, in addition to massive immunization of the Brazilian population. Without these measures, unfortunately, there will still be thousands of deaths to mourn in the near future.

\section{Acknowledgements}

We also thank our colleagues from the University of Brasília (UnB): Mauro Sanchez, Ivan Zimmermann and Everton Nunes; from the Sergio Arouca National School of Public Health (Ensp)/Oswaldo Cruz Foundation (Fiocruz): Claudia Pereira; from Fiocruz/AM: Fernando Herkrat and Rodrigo Lima for their contribution to the discussion of the study results.

\section{Collaborators}

Barreto ICHC (0000-0001-8447-3654)* and Santos LMP (0000-0002-6739-6260)* contributed equally to the conception of the study design; analysis and interpretation of data; drafting and approval of the final version of the manuscript. Costa Filho RV (0000-00022456-8819)* contributed to the conception of the study design, analysis and interpretation of data and preparation of the draft. Ramos RF (0000-0003-2841-1787)*, Martins NRAV (0000-0003-1162-8795)* and Andrade LOM (0000-0002-3335-0619)* also contributed to the analysis and interpretation of the data and preparation of the draft. Cavalcante FV (0000-0002-8706-0457)* and Oliveira LG (0000-0003-2399-3052)* also collaborated for data analysis and interpretation; drafting and approval of the final version of the manuscript.

${ }^{*}$ Orcid (Open Researcher and Contributor ID). 


\section{References}

1. Brasil. Ministério da Saúde. Coronavírus COVID-19: Diretrizes para diagnóstico e tratamento da COVID-19. Brasília, DF: Ministério da Saúde; 2020. 73 p. [acesso em 2020 mar 3]. Disponível em: https://saude.rs.gov.br/upload/ arquivos/202004/14140600-2-ms-diretrizes-covid-v2-9-4.pdf.

2. World Health Organization. Statement on the second meeting of the International Health Regulations (2005) Emergency Committee regarding the outbreak of novel coronavirus (2019-nCoV). [acesso em 2020 mar 3]. Disponível em: https://www.who.int/news/ item/30-01-2020-statement-on-the-second-meeting-of-the-international-health-regulations-(2005)-emergency-committee-regarding-the-outbreak-of-novel-coronavirus-(2019-ncov).

3. Fundação Oswaldo Cruz, Escola Nacional de Saúde Pública Sergio Arouca, Centro de Pesquisas e Estudos sobre Desastres. A gestão de riscos e governança na pandemia por COVID-19 no Brasil: análise dos decretos estaduais no primeiro mês, relatório técnico e sumário executivo. Rio de Janeiro: Fiocruz; 2020. [acesso em 2020 mar 3]. Disponível em: https://www.arca.fiocruz.br/bitstream/ icict/41452/2/relatorio_cepedes_gestao_riscos_covid19_final.pdf.

4. Garcia PJ, Alarcón A, Bayer A, et al. COVID-19 Response in Latin America. Am J Trop Med Hyg. 2020 [acesso em 2020 mar 3]; 4;103(5):1765-72. Disponível em: https://ajtmh.org/doi/10.4269/ ajtmh.20-0765.

5. Brasil. Covid-19: Painel Coronavírus. 2021 [acesso em 2020 mar 3]. Disponível em: https://covid. saude.gov.br/.

6. Goya N, Andrade LOM. O Sistema Único de Saúde e o desafio da gestão regionalizada e contratualizada. Rev Bras em Promoção da Saúde. 2018 [aces- so em 2020 mar 3]; 31(4). Disponível em: http:// periodicos.unifor.br/RBPS/article/view/8773.

7. Conselho Nacional de Secretários de Saúde. Nota à imprensa - Aquisição de vacinas contra a Covid-19 por empresas. 2021. [acesso em 2020 mar 3]. Disponível em: https://www.conass.org.br/nota-a-imprensa-aquisicao-de-vacinas-contra-a-covid-19-por-empresas/.

8. Brasil. Ranking IDHM Municípios 2010. [acesso em 2020 mar 3]. Disponível em: https://www. br.undp.org/content/brazil/pt/home/idho/rankings/idhm-municipios-2010.html.

9. Instituto Brasileiro de Geografia e Estatística. Panorama Cidades. 2020 [acesso em 2020 mar 3]. Disponível em: https://cidades.ibge.gov.br/brasil/panorama.

10. Instituto Brasileiro de Geografia e Estatística. Estimativa da População IBGE. [acesso em 2021 jan 27]. Disponível em: https://www.ibge.gov.br/es tatisticas/sociais/populacao/9103-estimativas-de-populacao.html?=\&t=resultados .

11. Brasil. CNESNet. DATASUS. 2021. [acesso em 2021 jan 27]. Disponível em: http://cnes2.datasus.gov. $\mathrm{br} /$.

12. Instituto Brasileiro de Geografia e Estatística. Censo Demográfico. 2010. [acesso em 2021 jan 27]. Disponível em: https://www.ibge.gov.br/estatisticas/ sociais/populacao/9662-censo-demografico-2010. html?edicao $=9754 \& \mathrm{t}=$ resultados .

13. Google. COVID-19: Relatórios de mobilidade da comunidade. [acesso em 2021 jan 29]. Disponível em: https://www.google.com/covid19/mobility/.

14. StatCounter. Mobile Operating System Market Share Brazil from Apr 2020 - Apr 2021. StatCounter. 2021. [acesso em 2021 jan 27]. Disponível em: ht- 
tps://gs.statcounter.com/os-market-share/mobile/brazil.

15. Newzoo. Global Mobile Market Report. Newzoo. 2019. [acesso em 2021 jan 27]. Disponível em: https://newzoo.com/insights/trend-reports/ newzoo-global-mobile-market-report-2019-light-version/.

16. Instituto Brasileiro de Geografia e Estatística. Estimativas de População: Tabela 6579 - População residente estimada. IBGE. 2020. [acesso em 2020 jan 20]. Disponível em: https://sidra.ibge.gov.br/tabela/6579.

17. Leis Municipais. Tenha conhecimento das Leis criadas pelo seu município e Governo do Estado, a respeito do novo Coronavírus (COVID-19). Leis Municipais. 2020. [acesso em 2021 jan 20]. Disponível em: https://leismunicipais.com.br/coronavirus.

18. Centro de Estudos e Pesquisas de Direito Sanitário. Conectas Direitos Humanos. Direitos na Pandemia: Mapeamento e Análise das Normas Jurídicas de Resposta à COVID-19 no Brasil. São Paulo: CEPEDISA; 2021. [acesso em 2020 jan 20]. Disponível em: http://cepedisa.org.br/wp-content/ uploads/2020/07/02boletimcovid_PT_06.pdf.

19. Centro de Estudos e Pesquisas de Direito Sanitário. Conectas Direitos Humanos. Direitos na Pandemia: Mapeamento e Análise das Normas Jurídicas de Resposta à COVID-19 no Brasil. São Paulo: CEPEDISA; 2020. [acesso em 2020 jan 20]. Disponível em: http://cepedisa.org.br/wp-content/ uploads/2020/07/02boletimcovid_PT_06.pdf.

20. Li Y, Campbell H, Kulkarni D, et al. The temporal association of introducing and lifting non-pharmaceutical interventions with the time-varying reproduction number (R) of SARS-CoV-2: a modelling study across 131 countries. Lancet Infect Dis. 2021 [acesso em 2020 jan 20]; 21(2):193-202. Disponível em: https://linkinghub.elsevier.com/retrieve/pii/ S1473309920307854.
21. Calmon TVL. As condições objetivas para o enfrentamento ao COVID-19: abismo social brasileiro, o racismo, e as perspectivas de desenvolvimento social como determinantes. NAU Soc. 2020 [acesso em 2020 jan 20]; 11(20):131. Disponível em: https://portalseer. ufba.br/index.php/nausocial/article/view/36543.

22. Patel JA, Nielsen FBH, Badiani AA, et al. Poverty, inequality and COVID-19: the forgotten vulnerable. Public Health. 2020; 183:110-1. Disponível em: https://linkinghub.elsevier.com/retrieve/pii/ S0033350620301657.

23. Albuquerque B, Freitas CM, Barcellos C, et al. Nota Técnica no 04. Reflexões sobre o comportamento da epidemia da COVID-19 segundo as regiões de saúde do Estado do Amazonas. COVID-19 I. Rio de Janeiro: Fiocruz; 2021. [acesso em 2020 jan 20]. Disponível em: https://www.arca.fiocruz.br/handle/icict/45840.

24. Galvao TF, Tiguman GMB, Caicedo Roa M, et al. Inequity in utilizing health services in the Brazilian Amazon: A population based survey, 2015. Int J Health Plann Manage. 2019 [acesso em 2020 jan 20]; 12;34(4). Disponível em: https://onlinelibrary.wiley. com/doi/abs/10.1002/hpm.2902.

25. Fundação Oswaldo Cruz. Nota Técnica 2021/01 Rede Genômica FIOCRUZ / Ministério da Saúde. Rio de Janeiro: Fiocruz; 2021. [acesso em 2020 jan 20]. Disponível em: https://portal.fiocruz.br/sites/ portal.fiocruz.br/files/documentos/nota_tecnica_ ms_2021-01-12.pdf.

26. Sabino EC, Buss LF, Carvalho MPS, et al. Resurgence of COVID-19 in Manaus, Brazil, despite high seroprevalence. Lancet. 2021 [acesso em 2020 jan 20]; 397(10273):452-5. Disponível em: https://linkinghub. elsevier.com/retrieve/pii/S0140673621001835.

27. Ximenes RA, Albuquerque MFP, Martelli CMT, et al. COVID-19 No Nordeste do Brasil: Entre o Lockdown e o Relaxamento das Medidas de Distanciamento Social. Ciênc. Saúde Colet. 2021 [acesso em 2020 jan 20]; 26(4):1441-1456). Disponível em: http://www. 
cienciaesaudecoletiva.com.br/artigos/covid19-no-nordeste-do-brasil-entre-o-lockdown-e-o-relaxamento-das-medidas-de-distanciamento-social/179 13 ? id=17913\&id=17913\&id=17913.

28. Fortaleza. Prefeitura Municipal. Secretaria Municipal de Saúde. Coordenadoria de Vigilância à Saúde. Boletim Epidemiológico. Inf Sem COVID-19. [acesso em 2020 jan 20]. Disponível em: https://coronavirus. fortaleza.ce.gov.br/boletim-epidemiologico.html.
29. Ceará. Secretaria da Saúde do Estado. Histórico de Internações por Covid-19. IntegraSUS. 2021. [acesso em 2021 fev 5]. Disponível em: https://indicadores. integrasus.saude.ce.gov.br/indicadores/indicadores-coronavirus/historico-internacoes-covid.

Received on $02 / 11 / 2021$

Approved on 07/02/2021

Conflict of interests: non-existent

Financial support: Public Call MCTI/CNPq/CT-Saúde/MS/SCTIE/

Decit No. 07/2020 